\title{
Icing ridges: A sedimentary criterion for recognizing former occurrence of icings
}

\author{
OLE HUMLUM
}

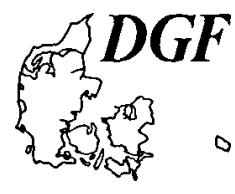

\begin{abstract}
Humlum, O.: Icing ridges: a sedimentary criterion for recognizing former occurrence of icings. Bull. geol. Soc. Denmark, vol. 28, pp. 11-16, Copenhagen. October 23rd, 1979. https://doi.org/10.37570/bgsd-1979-28-03

Small-scale deformations of glaciofluvial sediments is described from a Greenland outwash plain partly covered by icings (Aufeis, naleds). On the surface these deformations takes the form of small ridges, parallel to the margin of the icings. Formation of the ridges is ascribed to processes during disintegration

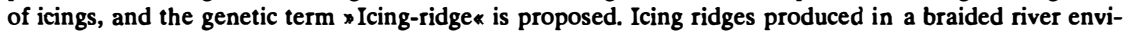
ronment are considered as most likely to be preserved at the base of small-scale coarsening upward sequences.
\end{abstract}

Ole Humlum, Department of Geography, Laboratory of Geomorphology, University of Copenhagen, Haraldsgade 68, DK 2100 Copenhagen $\emptyset$, Denmark, February 22nd, 1979.

Icing (german: Aufeis, russian: naleds) are sheets of freshwater ice which form in periglacial environments such as flood plains by overflowing of the stream during freeze-up (Washburn 1973, p. 29-30). Icings may also form as the result of ground water coming to the surface in natural seepages or springs. The ice sheet may be $1-5 \mathrm{~m}$ thick, and tends to be stratified parallel to the surface of deposition. Each layer consists of vertical, columnar ice crystals usually 1-15 cm high. The formation of icings is favoured by underlying permafrost (Washburn 1973, p. 30), and icings are known to be preserved for a long time when buried under debris that insulates it from melting. Most accumulations of icings, however, disappear totally or partly each summer, but may be reformed during the following winter. Many icings cover areas of $0.1-1 \mathrm{~km}^{2}$, but a few Sibirian examples are known to be as large as $20-50 \mathrm{~km}^{2}$.

Kettle holes in outwash plains are usually interpreted as a result of the melting of buried or stranded blocks of glacier ice (see e.g. Flint 1973, p. 212). Recently, Kozarski (1975) however has drawn attention to the fact that many shallow (less than $5 \mathrm{~m}$ deep) kettle holes oriented in rows may as well be interpreted as the result of icings, melted after burial under fluvioglacial deposits thus not necessary indicating the former presence of glacier ice. Also Svensson (1977), working on the glaciofluvial plains in southwestern Sweden, proposed that icings were active during the formation of small valleys with distinct flat bottom, incised into the plains. Relict patterns of ice-wedge polygons on the plains indicated periods (Older Dryas, Yonger Dryas, cf. Svensson 1973) of periglacial climate, in which icings may have existed in the area.

In continuation of the findings and proposals of Kozarski and Svensson, and specially because many former icings may never have been buried, it is of palaeoenvironmental interest to search for evidence of the former existence of non-buried icings in sedimentary sequences. In this respect, the following observations and discussion may have interest - even though the observations are limited and qualitative in nature.

\section{Observations}

The observations to be described were made in the valley of Blæsedalen, southern Disko Island $\left(54^{\circ} \mathrm{W}, 70^{\circ} \mathrm{N}\right)$, W. Greenland. This valley runs north-south with a, valley train fed by several outlet-glaciers from the local ice cap Lyngemarkens Iskappe. During the winter, fairly large (apr. $700.300 \mathrm{~m}$ ) icings usually form over the lower (southernmost) part of the valley bottom. The icings reach a thickness of $1-2 \mathrm{~m}$, and as a rule disappears totally each summer. The author carried out geomorphological mapping in this area during the summer of 1976, and made some observations on the melting and disintegration of the icings. 


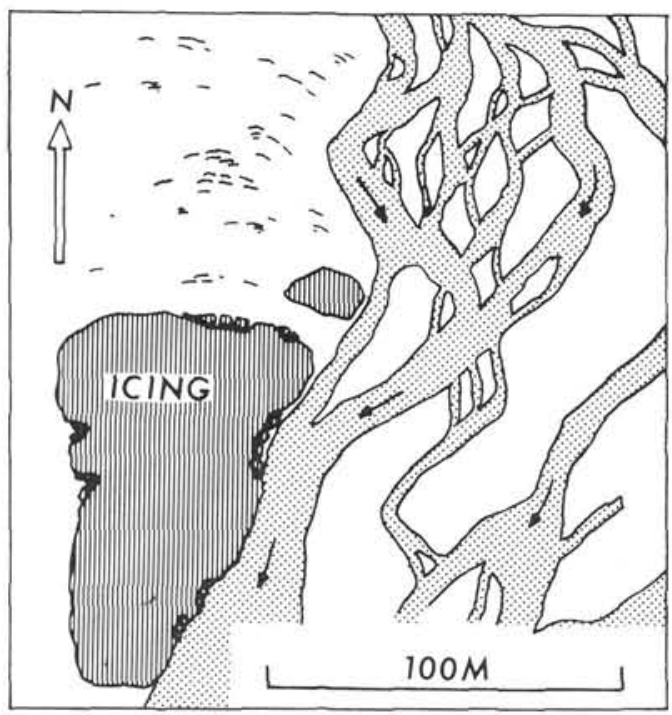

Fig. 1. Map showing the study area in Blasedalen, Disko Island, W. Greenland. The overall outline of small gravel ridges are shown in the area north of the icing.

In august 1976 icings in Blæsedalen was reduced to about $120.60 \mathrm{~m}$ (Fig. 1), and lay on the surface of the flood plain with no obvious risk of being buried (Fig. 2). Especially conspicuous features associated with the area north of the ice sheet were numerous small $(5-10 \mathrm{~cm}$ high, 5-15 $\mathrm{cm}$ wide) gravel ridges with intervening smooth stone pavements (Fig. 3). In most cases an individual gravel ridge could be followed for about $4-6 \mathrm{~m}$, and occationally up to $15 \mathrm{~m}$. The orientation of the ridges varied somewhat, but they displayed a distinct tendency to parallel the overall outline of the melting icing to the south (Fig. 1).

It was noted that the icing was melting especially fast at the lower part of the almost vertical sides (Fig. 2), apparantly because of energy emitted from the surrounding sun-heated gravel, and locally because of contact with running water. Consequently, the icing was disintegrating from the margin by collapse of large ice blocks (Fig. 2 and 4).

Most of the collapsed ice blocks were $3-5 \mathrm{~m}$ in diameter, and usually a small ridge consisting of gravel could be seen along the outer front of fallen blocks (Fig. 4). These gravel ridges was in size and configuration similar to the gravel ridges observed in the area north of the icing. Both the ridges at fallen ice blocks and ridges further from the icing displayed a slightly convex outline in
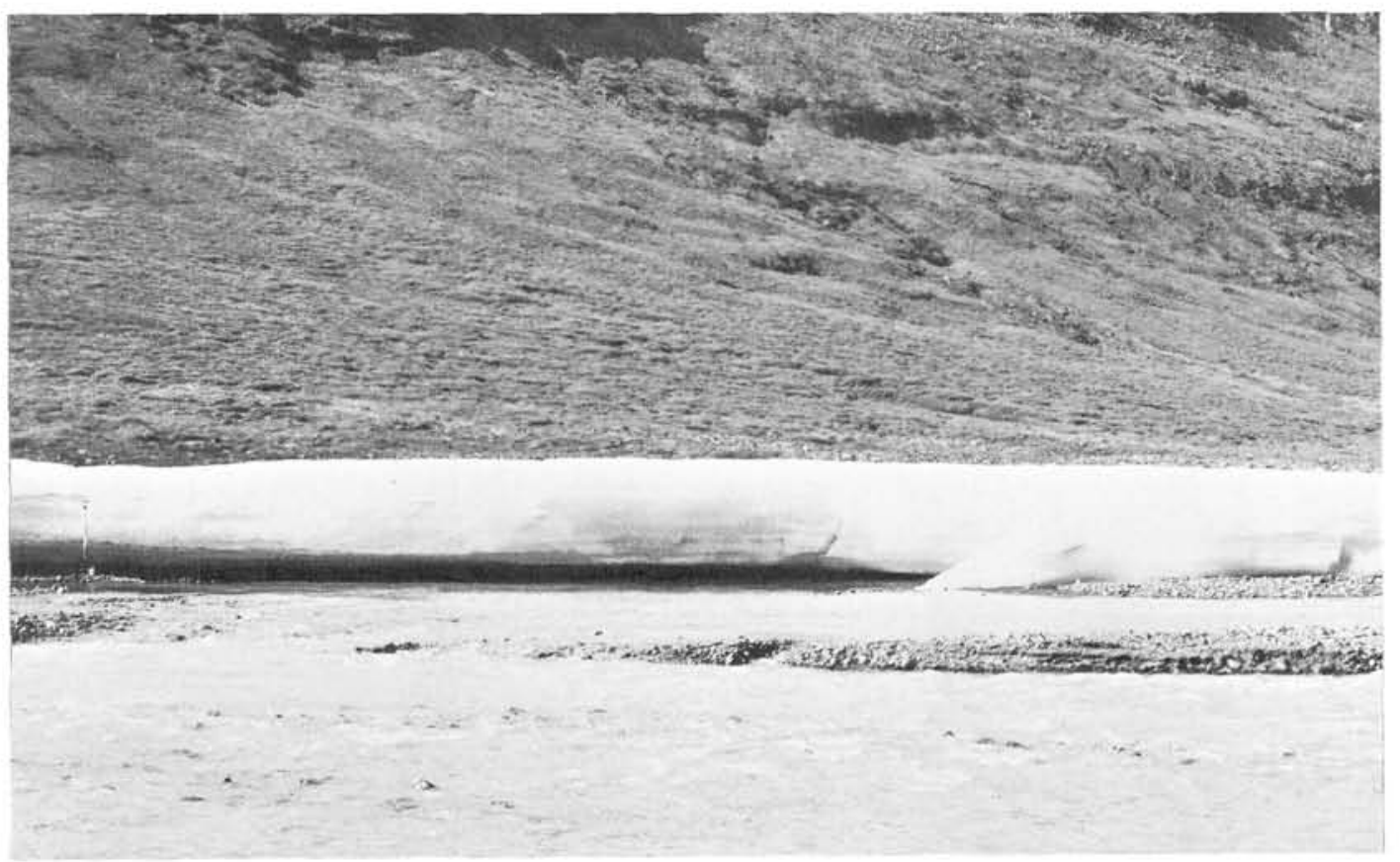

Fig. 2. The icing in Blaesedalen (29-07-1976). The sheet of ice is about $1.5 \mathrm{~m}$ thick, note the spade at the extreme left for scale and the capsized ice block to the right. 


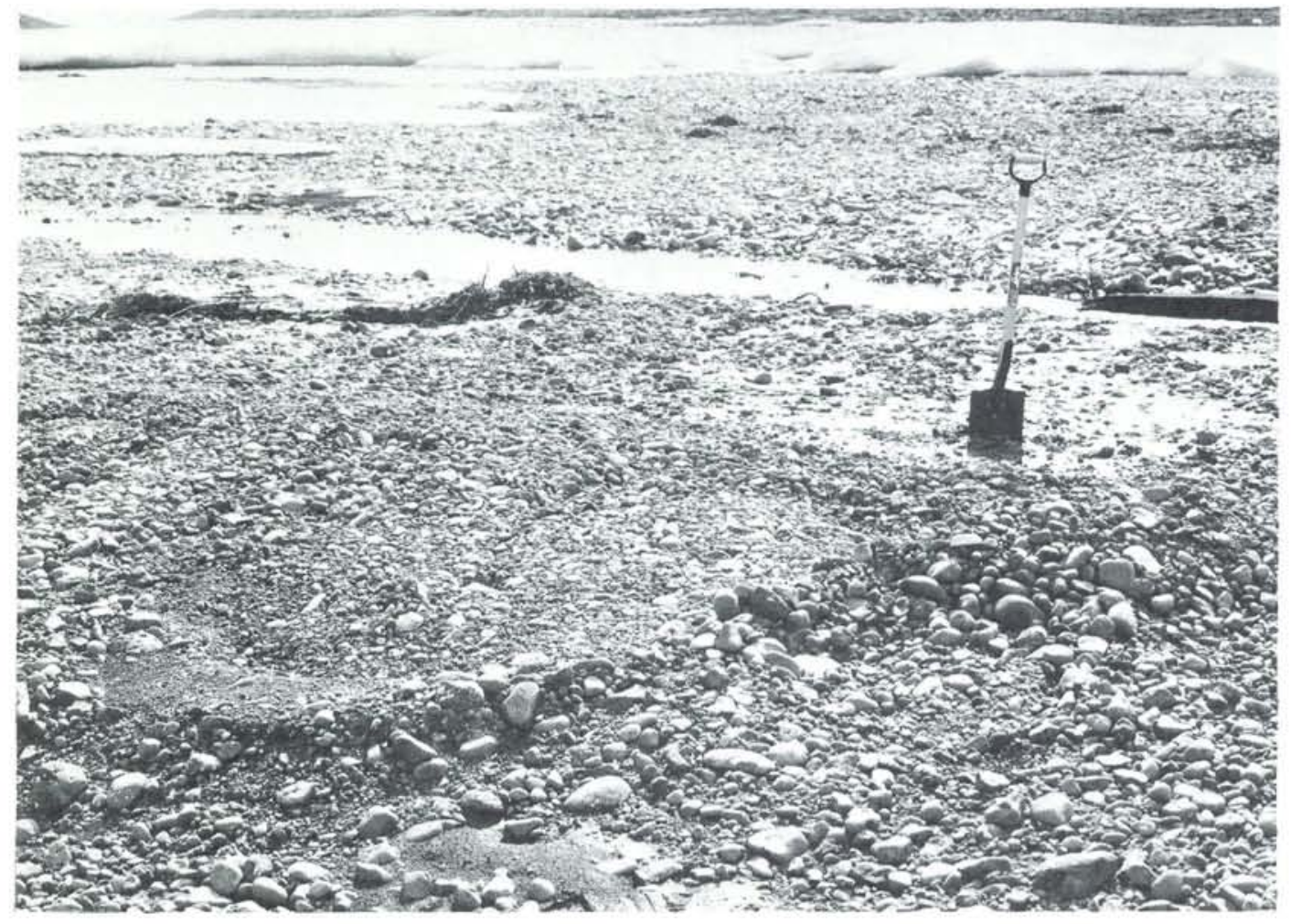

Fig. 3. Gravel ridge and associated stone pavement on the far (proximal) side of the ridge. The disintegrating icing is seen in the background.

direction away from the icing, that is, against the general direction of water flow (Fig. 1). A profile across the gravel ridge from figure 3 is shown in figure 5. In this figure, which is based on a field sketch, the deformation fabric visually characterizing the interior of the icing ridge should be noticed, as several elongated particles dips toward the receding icing (to the left), that is in this case against the up-stream imbrication (toward the right) characterizing the remaining part of the section. Furthermore, also the weak pavement to the left (proximal, in direction of the icing) of the ridge should be noticed.

\section{Interpretation}

No capsize of ice blocks at the icing was observed during the stay at the locallity, but it seems obvious that the observed ridges in contact with ice blocks (Fig. 4) were small thrust ridges caused by the impact of the falling ice blocks.
The other ridges in the area north of the icing were of equal appearance, and I would suggest them to be equivalent to the ridges observed in contact with the disintegrating icing. Because of their length it is considered unlikely that these ridges should be interpreted as the result of push by river ice during the spring flood. Also their tendency to display a slightly convex outline against the flow (from the north) lend some support to this suggestion, as does the presence of proximal (toward the icing) pavements.

My hypothesis is therefore that all ridges observed were formed by the thrust of collapsing ice blocks from the edge of the receding icing, thus forcing the fluvial sediments upwards and outwards at the outer front of the collapsed ice blocks. For ridges originating in this way the genetic term Icing ridge is proposed. Icing ridges should accordingly be classified as a special type of tool marks (Reineck and Singh 1975).

If small ridges like those described above should escape later destruction, the observation 


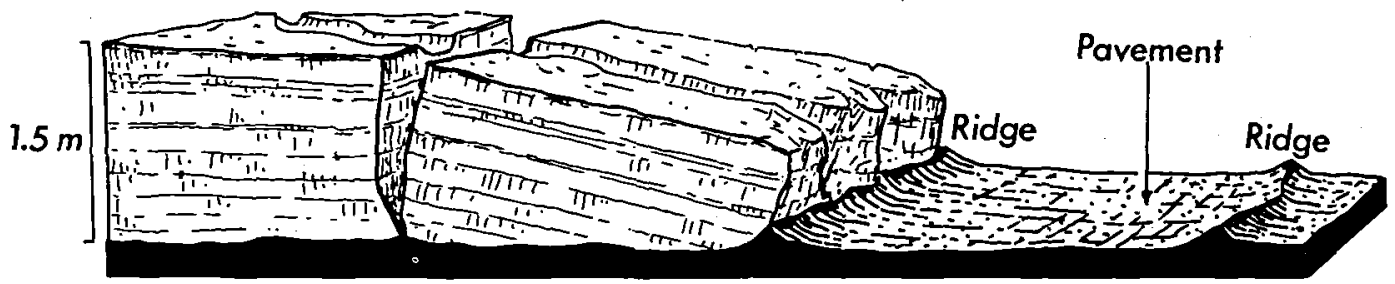

Fig. 4. Field sketch of the disintegrating icing in Blasedalen. A small gravel ridge is formed by the thrust of the collapsed ice block. Also the pavement (Fig. 3) originates from this process.

of the corresponding deformation structure (Fig. 5 ) in fluvial sediments could prove to be a criterion for recognizing former occurrence of non-buried icings; i.e. indicating a periglacial environment at the time when the sediments were laid down.

However, push by river ice or by other floating objects might be expected to generate ridges or structures somewhat like those described from Blæsedalen. This obviously represents a problem concerning the palaeoclimatic implication, as grounding structures may well be generated far from periglacial regions.

Observations from fluvial environments indicate that the grounding of floating objects usually results in a long and shallow groove/drag mark only (Slatt and Hoskin 1968, Gustavson 1974), bearing no resemblance to ridges like those described above. In some cases, however, the grounding of floating objects may be expected to generate a push ridge with vertical dimensions of the same order of magnitude or larger than icing ridges. Examples of this - with ridges generated by ice floes - have been discribed from an arctic beach by Clemmensen and Surlyk (1975), as it has been observed on tidal flats in the southern North Sea (Reineck 1956, Reineck and Singh 1975), and resembling tool marks may be expected to occur in a fluvial environment. Misinterpretations should be avoided by noting that push ridges usually are associated with a distinct depression or groove on the proximal side of the ridge, and a transversal profile is thus expected to show a step-like arrangement of the surface across the ridge; a feature not displayed by the profile shown in figure 5 , where the sediment surface reach almost identical levels of either side of the icing ridge. Furthermore, the length of grounding ridges is generally expected to be considerably shorter than the observed length of icing ridges $(5-6 \mathrm{~m}, \max .15 \mathrm{~m})$. Therefore, the grounding of floating objects is not considered as a serious possiblilty for misinterpretations.

In another way stranded or buried blocks of ice

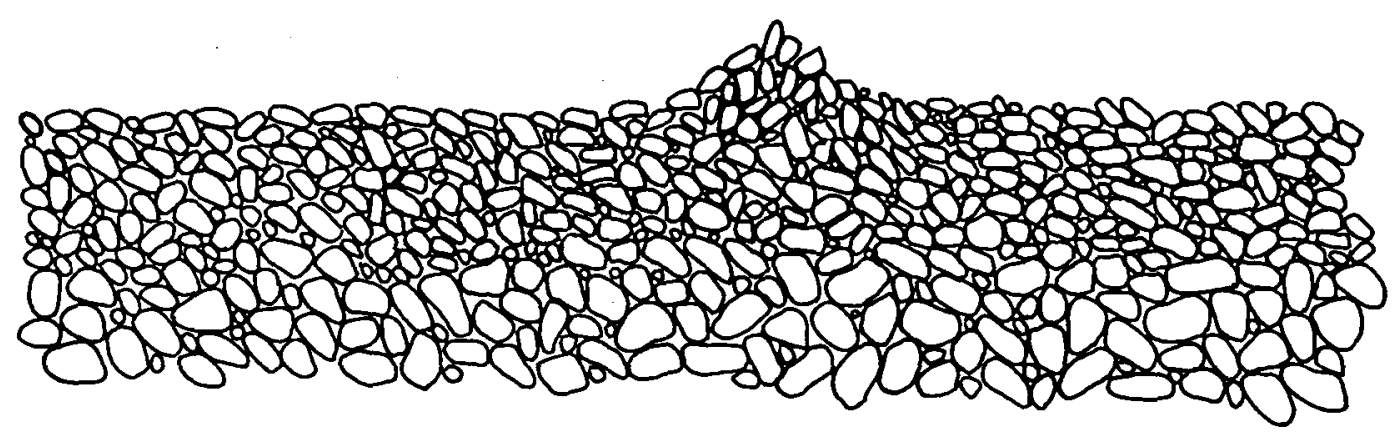

$1 \mathrm{M}$

Fig. 5. Vertical cross-section of one of the gravel ridges observed in Blasedalen. A collapsed ice block is assumed to have produced the pavement to the left of the ridge (comp. w. Fig. 4). 


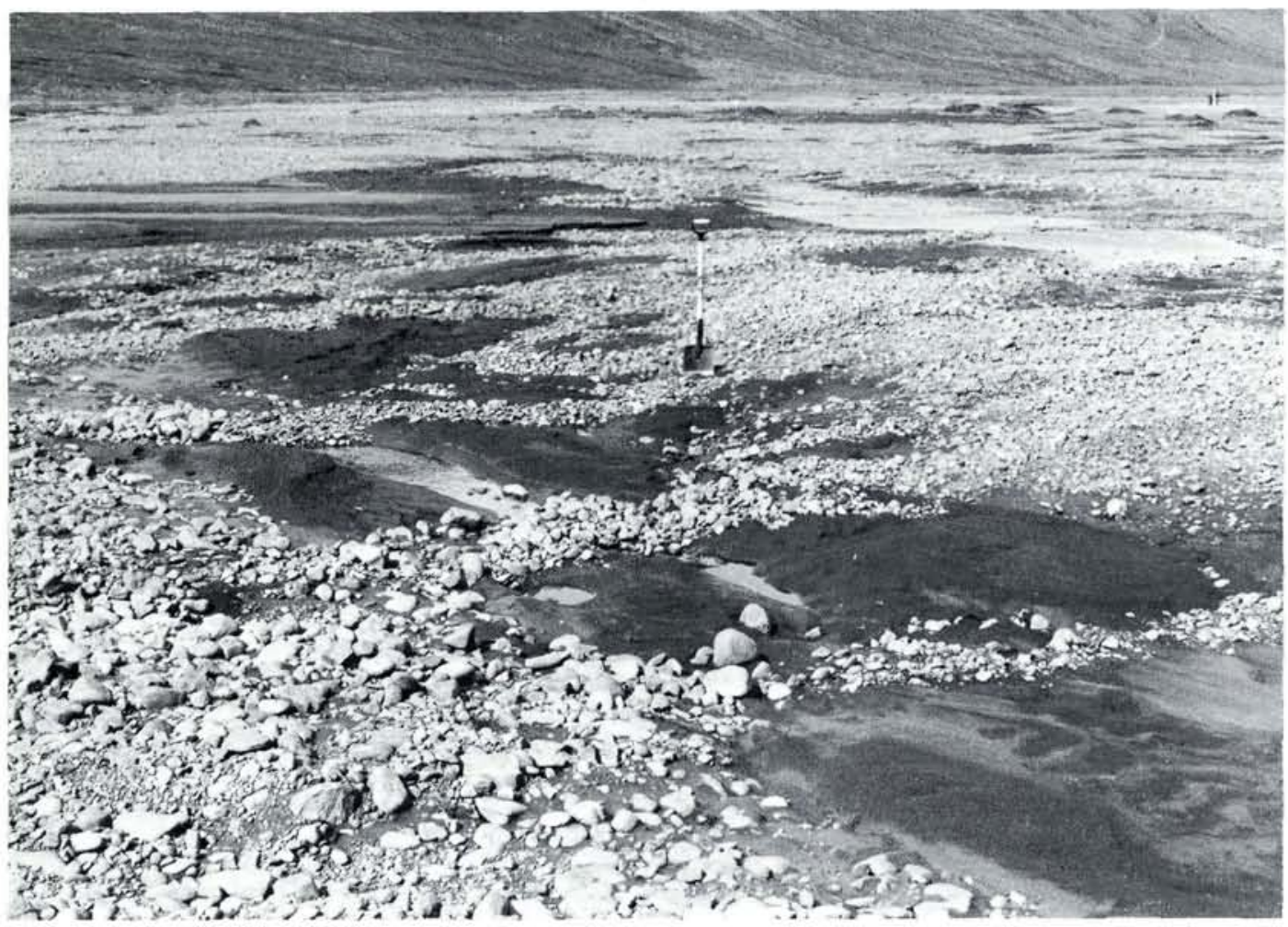

Fig. 6. A series of gravel ridges crossing a small channel undergoing fill during daily reactivations.

may pose a potential problem, as these often contain a considerable amount of debris, and they may thus leave an accumulation of sediment as the ice melts. Both Slatt and Hoskin (1968) and Gustavson (1974) have described accumulations of this kind in a fluvial environment, partly as small heaps of gravel, gravel nests, partly as concentric rings. From arctic beaches examples of this are presented by Clemmensen and Surlyk (1975) and by Nielsen (1978).

Maizels (1977) has experimentally investigated the type of surface form that melting blocks of ice (buried and non-buried) produce. She found that ice blocks melting on a dry or saturated surface of gravel create small ridges or heaps, much like those described by the above mentioned authors. Ridges produced by melting of ice blocks should, however, be easily distinguishable from icing ridges which originate as postdepositional small-scale deformations, and therefore always will consist of sediment similar to that found beneath the ridges, whereas it is highly improbable that sediment melting out from a stranded block of dirty glacier- or river ice should be identical to the fluvial sediments found around the block of ice. Therefore, stranded or buried blocks of dirty ice are not considered as a serious problem either.

\section{Preservation of icing ridges}

At the locallity in Blæsedalen, it was observed that later floodings could destroy the icing ridges, except where they lay across small channels dissecting channel bars or anabranches to such channels (second and third order channels by Williams and Rust 1969), predating the icing. Here, the icing ridges were buried by fine sediments during an early stage of channel reactivation (Fig. 6), and the ridges were later commonly found at the base of a small channel fill sequence consisting of $0-0.5 \mathrm{~cm}$ fine silt overlain by $0.1-0.3 \mathrm{~m}$ ripple-drift cross laminated sands of A- and B-type (Jopling and Walker 1968), indicating a general increase in the relative impor- 
tance of deposition from bed load upwards. This stratigraphy correspond to the basal part of a small coarsening upward sequence, by Costello and Walker (1972) proposed as a highly indicative, if not diagnostic criterion for braided streams.

Icing ridges produced in a braided river system as that in Blæsedalen are therefore considered as most likely to be preserved at the base of small-scale coarsening upward sequences in ancient fluvial sediments. Therefore, even when icing ridges seems to present a potential useful criterion for the recognition of former non-buried icings, it should be realized that only a fraction of icings in a braided environment will be detected by this criterion. Because of this, the proposed criterion should only be considered as »helpful « at the present state of knowledge, and this paper is put forward as an attempt to provocate further observations to be made in other environments.

Acknowledgements. The author is indebted to Professor Harald Svensson for drawing his attention to problems connected with icings and to the paper by Kozarski (1975). Further, I wish to thank Mrs. K. Winther for making suggestions as to the language of the manuscript.

\section{Dansk sammendrag}

Icings (tysk: Aufeis, russisk: naleds) er 1-5 m mægtige aflejringer af is, der dannes $\mathrm{i}$ forbindelse med floders og kildevælds tilfrysning om efteråret og vinteren. Icings optræeder derfor sadvanligvis $i$ terrænets lavninger, og er karakteristiske for periglaciale områder. En icing kan under gunstige omstæandigheder (fx. hvor den ligger over permafrost) overleve $i$ flere år, men mange icings smelter om sommeren og gendannes det følgende efterår og vinter. De fleste eksempler på recente icings er ikke større end $0,1-1 \mathrm{~km}^{2}$, men fra Sibirien kendes icings, der er mere end $50 \mathrm{~km}^{2}$ store.

Icings er et vigtigt studieobjekt, bl.a. fordi icings som af floder er begravet under et sedimentlag, ved senere smeltning kan resultere i sammensynkninger, der let kan fejltolkes som dødishuller efter smeltet gletscheris. De fleste icings begraves dog ikke, men af palaeoklimatologiske hensyn er det interessant at eftersoge spor efter også denne type icing.

Nogle observationer fra en smeltevandsslette på Disko, Grønland, peger på en mulighed for dette. På denne lokalitet er en recent icing iagttaget under smeltning $i$ sommerperioden, resulterende i gradvis sønderdeling af icingen ved løsgøring af store isblokke fra icingens rand (fig. 2 og 4). Når disse blokke vælter ud over det omgivende sediment, dannes en lille oppresningsvold i dette langs blokkenes yderkant (fig. 4). Små oppresningsvolde af denne type (5-15m lange, $5-10 \mathrm{~cm}$ høje, 5-15 cm brede) må anses for karakteristiske for et sedimentationsmiljø med icings, og de foreslås benæunt icing ridges. $\mathrm{På}$ fig. 5 er vist et tvarsnit gennem oppresningsvolden vist på fig. 3 . 1 forbindelse med et braiderende flodsystem anses bevaringspotentialet for icing ridges for maximalt i små løb, hvor ryggene kan begraves under fint sediment. I lodrette profiler i sedimenter aflejret af braiderende floder forventes icing ridges derfor især at være bevaret ved basis af small-scale opad-grovere sekvenser (sml.m. Costello og Walker 1972).

\section{References}

Clemmensen, L. and Surlyk, F. 1975: En arktisk tidevandskyst. Varv, Mineralogisk Museum, University of Copenhagen, 1 , 3-10.

Costello, W. R. and Walker, R. G. 1972: Pleistocene sedimentology, Credit River, Southern Ontario: a new component of the braided river model. Journ. Sed. Petrol., 42, 2: 389-400.

Flint, R. F. 1971: Glacial and Quaternary geology. Wiley \& Sons, New York, 892 p.

Gustavsson, T. C. 1974: Sedimentation on Gravel Outwash Fans, Malaspina Glacier Foreland, Alaska. Joum. Sed. Petrol., 44, 2: 374-389.

Jopling, A. V. and Walker, R. G. 1968: Morphology and origin of ripple-drift cross-lamination, with examples from the Pleistocene of Massachusetts. Journ. Sed. Petrol., 38, 4: 971-984.

Kozarski, S. 1975: Oriented kettle holes in outwash plains. Quaestiones Geographicae, 2: 99-112.

Maizels, J. K. 1977: Experiments on the origin of kettle-holes. Journ. Glaciol., 18, 79: 291-303.

Nielsen, N. 1978: Kystmorfologi i arktiske områder. Geografisk Orientering, Geografforbundet, 8, 1: 242-246.

Reineck, H.-E. 1956: Abschmelzreste von Trebeis an den Ufersäumen des Gezeiten-Meeres. Senckenvergiana Lethana 37: 299-304.

Reineck, H.-E. and Singh, I. B. 1975: Depositional Sedimentary Environments. Springer-Verlag, Berlin Heidelberg, New York, 439 p.

Slatt, R. M. and Hoskin, C. M. 1968: Water and Sediment in the Norris Glacier Outwash Area, Upper Taku Inlet, Southeastern Alaska. Journ. Sed. Petrol., 38, 2: 434-356.

Svensson, H. 1973: Distribution and chronology of relict polygon patterns in the Laholm Plain, The Swedish west coast. Geografiska Annaler, 55A, 3-4: 159-175.

Svensson, H. 1977: En fossil dalform på Laholmsslätten. Svensk Geografisk Arsbok 53: 116-125.

Washburn, A. L. 1973: Periglacial processes and environments. Edward Amold, London, 320 p.

Williams, P. F. and Rust, B. R. 1969: The sedimentology of a braided river. Journ. Sed. Petrol., 39, 2: 649-679. 